\title{
The Validity of Science Learning Devices Based on the 7E Learning Cycle Model to Improve Concept Mastery of Junior High School Students
}

\author{
*Muliadi Rahman, Agus Ramdani, Jamaludin \\ Magister of Science Education Program, Universitas Mataram, J1. Majapahit No.62, Mataram, \\ Indonesia, 83115
}

*Corresponding Author e-mail: muliadirahman42@gmail.com

Received: May 2021; Revised: June 2021; Published: June 2021

\begin{abstract}
This study aimed to develop a science learning tool based on the 7E learning cycle model that is valid to improve the mastery of concepts and science process skills for Junior high school students. The device development carried out refers to the Research and Development (R \& D) development model based on the Thiagarajan 4D development model which includes the design, define, develop and disseminate stages. Based on the results of validation by 3 expert validators, it was obtained that the average value of the validity of the learning learning tools developed included the Syllabus $83.33 \%$, lesson plan $81.48 \%$, student worksheet 74.17\%, Concept Mastery Assessment Instruments $77.78 \%$ and science process skills tests $80.00 \%$. Based on the results of validation by 3 validators, In conclusion, the science learning device based on the 7E learning model developed is valid for use in learning.
\end{abstract}

Keywords: Validity; Science Learning Tools; Learning cycle 7E; Concept Mastery

How to Cite: Rahman, M., Ramdani, A., \& Jamaluddin, J. (2021). The Validity of Science Learning Devices Based on the 7E Learning Cycle Model to Improve Concept Mastery of Junior High School Students. Prisma Sains : Jurnal Pengkajian Ilmu dan Pembelajaran Matematika dan IPA IKIP Mataram, 9(1), 108-113. doi:https://doi.org/10.33394/j-ps.v9i1.3976

https://doi.org/10.33394/j-ps.v9i1.3976

Copyright@ 2021, Rahman et al This is an open-access article under the CC-BY License. (c) (i)

\section{INTRODUCTION}

Learning tools wer learning activities that contain learning plans that describe the competencies to be achieved, the design of the learning process according to the learning model, and instruments to measure the achievement of student competencies (Majid, 2008; Jamil, 2014; Prasetyo, 2011). The learning tools needed consist of syllabus, lesson plans, teaching materials, media and assessment tools (Jamil, 2014; Tanjung \& Nababan, 2018). Learning tools become a guide for teachers in carrying out learning in the classroom, laboratory or outside the classroom (Devi, 2009). Learning tools must be adapted to the learning model that will be used. Teachers are required to use appropriate, appropriate and more meaningful learning models for students so that students are actively involved in the learning process.

The designed learning model can describe a process of learning activities and the creation of environmental situations in a systematic way that allows students to interact, so that changes or developments occur in students (Sugiana et al. 2017). The selection of the right learning model in the science learning process will affect the interests and abilities of students. Direct learning models require teachers to provide information, demonstrate the skills being taught, and then provide time for students to practice those skills and receive feedback on what they are doing. The learning model that involves the active role of students participating directly in the learning process that can construct the initial knowledge and experience possessed by students is the $7 \mathrm{E}$ Learning Cycle Model. The 7E learning cycle model is an application of a constructivist learning model that is student centered and always 
involves students directly in each phase so that students can apply lesson concepts and remember well the material they have learned. This is confirmed by Yunita (2014) that the constructivism-based science learning model and the learning method are student-centred by actively involving them through 7 phases in learning, namely learning cycle 7E (learning cycle).

Learning the 7E learning cycle model is expected to help students to be able to develop their knowledge. Qarareh (2012) explains learning cycle 7E is an active cognitive process, students go through various exploratory experiences that allow students to explore knowledge intended for human thought. Learning to use the 7E learning cycle as meaningful learning will improve students' achievement and understanding of science. This is based on the research of Spencer and Guillaume (2006) which states that the learning cycle when applied in learning can improve science achievement (including concept recall) and improve scientific attitudes and processes and have a positive effect on understanding science.

The Learning Cycle 7E learning model can develop students' concept mastery, provide opportunities for students to conduct science experiments directly, and meaningful learning process. The 7E learning cycle developed by Eisenkraft (2003) consists of seven wellorganized phases, namely elicit, engage, explore, explain, elaborate, evaluate, and extend. There is a phase in the 7E learning cycle model called the explore phase, in which students will explore their knowledge through experimental activities. This model will provide opportunities for students to be actively involved and use all knowledge to find answers or conclusions from problems given through experimental activities in the explore phase (Lawson, 1995). Students will find and develop their own knowledge in the explore phase, so that the knowledge gained will be recorded more strongly in memory.

From the results of initial observations in a preliminary study at schools on January 22 , 2020 by interviewing science teachers, several problems were found, including: 1) the subject matter provided is in the textbook or teacher's handbook, 2) learning is only dominated by the teacher, 3) emphasis is placed on the teacher. Science learning is just an understanding of concepts, 4) in learning activities, students are usually asked to summarize the subject matter and do the exercises in the book, 5) the semester MID score is still less than the specified KKM value (70). This is in accordance with the opinion conveyed by Yustiqvar, et al (2019) that many students in fact only memorize science concepts without actually studying. In addition, Amijaya, et al (2018) stated that the learning process still tends to be centered on educators. This causes students to tend to be passive and only accept material from what has been conveyed by educators without developing it independently so that students are not able to develop their thinking skills.

The science learning process is more focused on the activeness of students, in general, teachers tend to convey information in one direction only through lectures. Providing information and concepts without any scientific investigation that makes students only memorize without understanding the material being studied. Learning using the lecture method is not suitable for use in science learning because students do not play an active role, reduce the ability to think, work and behave scientifically and discuss between students. According to Setyorini \& Subali (2011) this problem is caused by teachers who are more dominant in using the lecture method due to limited teaching time, material targets and inadequate infrastructure so that learning becomes monotonous and passive which has an impact on students' abilities. This study aim to develop a suitable science learning device based on the 7E learning cycle model to improve students' mastery of concepts.

\section{METHOD}

This research includes research and development (R \& D). According to Sugiyono (2012) research and development Research and Development (R \& D) is a research method used to produce certain products, and test the effectiveness of these products. The main purpose of research and development Research and Development (R \& D) is not to formulate 
or test theories but to develop effective results for use in schools or other institutions (Darmadi, 2011). This research refers to Thiagarajan's research and development model, namely 4D (Define, Design, Develop, Disseminate). The tools developed are syllabus, lesson plans, student worksheet and concept mastery assessment instruments.

Before the learning framework developed can be used at the research stage, a feasibility test is first carried out. The results of the feasibility test are used as the basis for revising the learning tools developed. The learning tools validity test was carried out by three expert validators by filling out the validation sheet. Expert validation data were analyzed to determine the level of validity using the percentage validity formula (Borich, 1994).

\section{RESULTS AND DISCUSSION}

Science learning tools based on the 7E learning cycle model that were developed include the syllabus, lesson plans, LKPD, concept mastery assessment instruments and students' scientific process skills assessment instruments before being tested on a limited and broad scale first tested for validity by 3 expert lecturers. The following is the average value of the expert validation results.

\section{Device Validation}

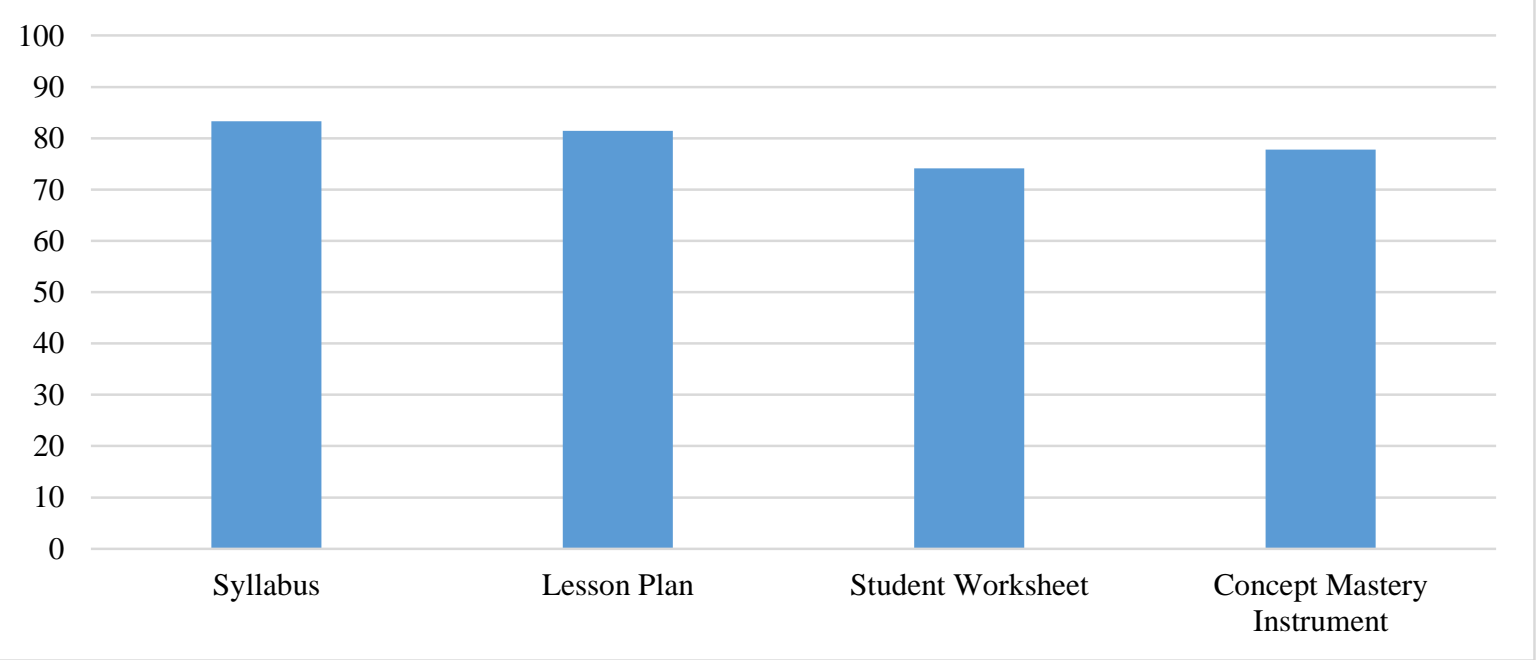

Figure 1. Results of the average value of expert validators

Based on the assessment of each expert validator on the science learning tools based on the 7E learning cycle model that was developed, as shown in Figure 1, the syllabus has an average value of 83.33 with a decent category. The average value of the RPP is 81.67 with a decent category. The average value of the LKPD is 74.17 with a decent category. The average value of the concept mastery instrument is 77.78 . with a decent category and the average value of the science process skills instrument is 80.00 with a decent category.

The results of each validated device fall into the appropriate category according to the Likert scale. The validated aspects are in accordance with the Permendikbud guide number 22 of 2016 concerning content standards that have the characteristics of learning with the 7E learning cycle model. The 7E learning syntax is contained in the learning steps Elicite, Enggage, Explore, Explaine, Elaborate, Extende and Evaluate. The basic competencies developed are 3.10 and 4.10 according to the 2016 syllabus with the 7E learning syntax model. The development of science learning tools based on the 7E model aims to improve students' mastery of concepts and science process skills.

Based on Figure 2, it can be seen that the value of each validator is $88.89,80.74$ and 74.81. The average value of 81.48 is categorized as good. So it can be stated that the syllabus developed is suitable for use at the research stage.

The feasibility of the developed RPP is in accordance with Permendiknas Number 22 of 2016 concerning Process Standards, it is explained that the RPP is described from the 
syllabus to direct student learning activities in an effort to achieve basic competencies. The components contained in the lesson plan include: school identity, subject identity, class/semester, subject matter, time allocation, learning objectives, basic competencies and indicators of competency achievement, learning materials, learning methods, learning media, learning resources, steps learning steps, assessment of learning outcomes. Learning objectives are described from indicators, and formulated/written clearly, using operational verbs, and at least contains; students as learning objects, specific behaviors/competencies and learning materials. Specific behaviors/competencies and learning materials are an inseparable unit, because the writing of learning objectives cannot be based on one of them (specific behaviors/competencies or learning materials), although there are components of students as objects/learning orientations.

Based on the expert validator's assessment of the developed LKPD, as shown in the picture above, each validator is $86.67,62.5,73.33$ and an average of 74.17 with a decent category. The feasibility of this LKPD is supported by the aspects/components that become the study of the developed LKPD, which includes aspects of appearance, presentation of material and benefits.

LKPD is a teaching material containing subject matter that is packaged in such a way, so that students can learn independently and directed (Damayanti, Ngazizah, and Setyadi, 2013). The material contained in the LKPD is in accordance with the material contained in both the syllabus and lesson plans, so that it really supports the achievement of basic competencies. This is supported by Devi et. al., (2009), that the material contained in the LKPD supports the achievement of basic competencies, and the material can be taken from books, magazines, internet, research journals. The activities contained in the LKPD describe the actions or activities carried out by students. These actions or activities are a means to train students' scientific process skills and mastery of concepts. This is in line with the statement of Astuti and Setiawan (2013), that activities in the LKPD can improve students' scientific/inquiry process skills, and the questions contained in the LKPD aim to assist students in developing their thinking skills. Through science process skills and thinking skills, students are expected to have a good understanding of the material or concepts they are learning.

Based on the expert validator's assessment of the developed concept mastery, as shown in the picture above, the validators are $85 \%, 76.67 \%, 71.67 \%$ and an average of $77.78 \%$ with a decent category. This concept mastery test was developed to measure the students' mastery of concepts after going through the learning process.

Students are considered to have mastered a concept that has been taught if they can translate from an abstract state to another, from a symbolic form to another form or vice versa, and can interpret in the form of the ability to organize existing data according to the individual's own view (Rizal, 2014). . Students master the concept of the material that has been studied if they have captured the meaning of the concept and are able to solve problems related to the concept. Wahyuningsih et al. (2015).

Mastery of the concept referred to in this study is the ability of students to understand the concepts of the human excretory system, both concepts in theory and their application in daily life based on the cognitive aspects of Krathwohl's version of Bloom, namely C1, C2, C3, C4, C5 and C6.

The feasibility of assessing the mastery of the concepts developed on the human excretory system material for even semester 8th grade can be used at the research stage in a limited test at MTs Darusslam and a broad test at MTs Manba'ul Ulum and SMP Islam Bermi.

\section{CONCLUSION}

Science Learning Devices Based on the 7E Learning Cycle Model that were developed are valid for Improving Concept Mastery of Junior High School Students 


\section{RECOMMENDATION}

Science Learning Devices Based on the 7E Learning Cycle Model produced can be an alternative learning model applied by teachers in teaching science subjects.

\section{ACKNOWLEDGMENT}

This research received no specific grant from any funding agency in the public,commercial, or not-for-profit sectors.

\section{REFERENCES}

Aktamis, H., \& Ergin, Ö. (2008, June). The effect of scientific process skills education on students' scientific creativity, science attitudes and academic achievements. In AsiaPacific forum on science learning and teaching (Vol. 9, No. 1, pp. 1-21). The Education University of Hong Kong, Department of Science and Environmental Studies.

Amijaya, L. S., Ramdani, A., \& Merta, I. W. (2018). Pengaruh model pembelajaran inkuiri terbimbing terhadap hasil belajar dan kemampuan berpikir kritis peserta didik. Jurnal Pijar Mipa, 13(2), 94-99.

Astuti, Y., \& Setiawan, B. (2013). Pengembangan lembar kerja siswa (LKS) berbasis pendekatan inkuiri terbimbing dalam pembelajaran kooperatif pada materi kalor. Jurnal Pendidikan IPA Indonesia, 2(1), 88-92.

Borich, G. D. 1994. Observation Skills for Effective Teaching. Macmilla. Publishing Company: New York.

Darmadi, H. (2011). Metode Penelitian Pendidikan, Alfabeta. Bandung. (1).

Devi, K. P \& Sofiareni R. (2009). Pengembangan Perangkat Pembelajaran Untuk Guru IPA SMP. Bandung: PPPPTK IPA

Eisenkraft, A. (2003). Expanding the 5E model. Science Teacher-Washington-, 70(6), 56-59.

Lightburn, M. E., \& Fraser, B. J. (2007). Classroom environment and student outcomes among students using anthropometry activities in high-school science. Research in Science \& Technological Education, 25(2), 153-166.

Lubis, R. R., \& Lestari, R. (2017). Pengembangan Lembar Kerja Siswa Berbasis Inkuiri Untuk Kelas Viii Smp Negeri 5 Rambah Samo Pada Materi Gerak Pada Tumbuhan (Doctoral dissertation, Universitas Pasir Pengaraian).

Majid, A. (2008). Perencanaan Pembelajaran: Mengembangkan Standar Kompetensi Guru Cet. Bandung: Remaja Rosdakarya.

Nazir, M. (2011). Metode Penelitian, Cetakan Ke Tujuh. Bogor: Penerbit Ghalia Indonesia.

Ningrum, J. S. (2014). Strategi Pembelajaran Teori \& Aplikasi.

Prasetyo, Z. K., \& Senam, W. (2011). Pengembangan perangkat pembelajaran sains terpadu untuk meningkatkan kognitif, keterampilan proses, kreativitas serta menerapkan konsep ilmiah peserta didik SMP. Program Pascasarjana Universitas Negeri Yogyakarta.

Qarareh, A. O. (2012). The effect of using the learning cycle method in teaching science on the educational achievement of the sixth graders. International Journal of Educational Sciences, 4(2), 123-132.

Rizal, M. (2014). Pengaruh pembelajaran inkuiri terbimbing dengan multi representasi terhadap keterampilan proses sains dan penguasaan konsep IPA siswa kelas VIII SMP Negeri 2 Peukan Baro (Doctoral dissertation, Universitas Negeri Malang).

Rustaman, N., Dirdjosoemarto, S., Yudianto, S. A., Achmad, Y., Subekti, R., Rochintaniawati, D., \& Nurjhani, M. (2005). Strategi belajar mengajar biologi.

Setyorini, U., Sukiswo, S. E., \& Subali, B. (2011). Penerapan model problem based learning untuk meningkatkan kemampuan berpikir kritis siswa SMP. Jurnal pendidikan fisika indonesia, 7(1), 52-56. 
Siswono, H. (2017). Analisis pengaruh keterampilan proses sains terhadap penguasaan konsep fisika siswa. Momentum: Physics Education Journal, 2(1), 83-90.

Spencer, B. H., \& Guillaume, A. M. (2006). Integrating curriculum through the learning cycle: Content-based reading and vocabulary instruction. The Reading Teacher, 60(3), 206-219.

Sugiana, I. N., Harjono, A., Sahidu, H., \& Gunawan, G. (2017). Pengaruh model pembelajaran generatif berbantuan media laboratorium virtual terhadap penguasaan konsep fisika siswa pada materi momentum dan impuls. Jurnal Pendidikan Fisika dan Teknologi, 2(2), 61-65.

Sugiyono, M. (2015). Penelitian \& pengembangan (Research and Development/R\&D). Bandung: Penerbit Alfabeta.

Trianto, (2014). Model Pembelajaran Terpadu. Jakarta: Bumi Aksara

Wahyuningsih, W., Jamaluddin, J., \& Karnan, K. (2015). Penerapan pembelajaran Biologi berbasis macromedia flash dan implikasinya terhadap keterampilan metakognitif dan penguasaan konsep siswa kelas VIII SMPN 6 Mataram. Jurnal Pijar MIPA, 10(1), 4146

Yunita. (2014). Model-model pembelajaran kimia. Bandung: insan mandiri

Yustiqvar, M., Hadisaputra, S., \& Gunawan, G. (2019). Analisis penguasaan konsep siswa yang belajar kimia menggunakan multimedia interaktif berbasis green chemistry. Jurnal Pijar Mipa, 14(3), 135-140. 